\title{
Evaluating the Magnitude of Female Foeticide Problem of Punjab and Haryana A - Regional Analysis
}

\author{
*Dalbir Singh, **Satpal Singh \\ *Associate Professor Department of Geography Pt. NRS Govt. College Rohtak 124001 Haryana \\ **Executive Director-Vikaspath-A Society for Social Development \& Research, Rohtak-124001 (Haryana)
}

\begin{abstract}
Today, female foeticide problem is one of pressing problems of India. This problem has become a stigma and considered a sin in the Indian society. The problem has become aggravated particularly in the north-western part of India. In this context, various studies show that the male-child preference given by the masses which have given rise to skew the sex-ratio particularly the female proportionate figure in the age-group of 0-6 years. The present paper is an attempt to establish a 'cause-effect relationship for determine the attitude and the mind-set of the people for giving their preference to the male child, particularly in the rural areas. This study is an empirical study, carried out for all the districts of Punjab and Haryana indicate a considerable regional disparity, as revealed by the district-wise study, carried out in Punjab and Haryana. In order to testing the trends of female foeticides for both the states, a t-test has been applied, as a results it shows that the probability of incidence of female foeticides is more or less same in rural and urban areas in both the states, located in north-west part of India.
\end{abstract}

Keywords: Female Foeticide, skewed sex-ratio, cause-effect relationship, mind-set of people, regional disparity.

\section{Introduction}

Female foeticide is one of pressing social problems in India. In this context, it has been become a 'grim-situation' in north-western region of India. The states like Punjab and Haryana, which is one of the most affected regions with this burning problem of female foeticide in the country. The gravity of the problem has been indicated by the decaling sex-ratio; belong to within the age-group of 0-6 years (censuses 2011). The childsex ratio has been declined by $13 \%$. No doubt, there is considerable improvement in child ratio of Punjab and Haryana, which indicate a range between 45 to 55 percent. In this situation, the practices of son preference is not alienated to India only rather it is prevalent in many Asian countries where parents prize there are preferred because; they have a higher wage-earning capacity, especially recipients of the contrary, daughters are considered an economic burden because of prevailing dowry system in the society. After marriage they become members of the husband's family and their contribution to their parent family is negligible, therefore in resting in daughters will continue to be perceived as investing in another family's daughter in-law (Dasgupta, 2003). In the Hindu culture, only the sons are supposed to perform the last rites of parents to help them achieve salvation. There are varied socio-economic and demographic factors which determine the gender bias as well as strong prejudices against the female child (Bora, 2007).

Historically, most Asian countries have had a strong son preference. The South Asian countries have declining sex-ratios. In the beginning of the $20^{\text {th }}$ century, the sex-ratio in colonial India was 972 females per 1000 males, it declined by $-8,-11,-5,-5$, points in 1911, 1921, 1931 and 1941 respectively. It declined by $-5,-$ $11,-4,-7$ points, the decline in the juvenile sex India has tradition of killing female babies (custom of dudhapiti).According to first census conducted by Royal Administration during colonial period emphasis on male dominated population. Boys predominately among the Indian children, and high sex ratio were even recorded among older age-groups. Unfavourable death rates were indeed common among Indian women in all the ages. The practice of the female infanticide had been detected in some provinces of west India (Guil moto, 2005)

Prof. Amartya Kumr Sen, in his world famous article' Missing women' has statistically proved that during the last century, 100 million women have been missing in South Asia due to 'discrimination leading to death' experienced by them from womb to tomb in their life cycle. Selective elimination of female fetuses and selection of male, at a preconception stage contributes to more and more missing girls.

It is the psychic of the society which has always been proved a wet-blanket for the girl's child. Earlier, female infanticide was wide spread but usually, went often unnoticed due to the lack of duly registration of infant deaths, later on, with the introduction of sex determination technology it has now taken the shape of female foeticide.

This type of practices has changed the demographic picture of the country. It has been observed that the girls have been discriminated since the ancient period, and the boy's birth is always welcome. However, with 
the availability of medical technology has paved the way to make prediction of sex of an unborn child. Unfortunately, during 70's, India has established a new rather liberal law on abortion, which has paved the way for termination of a pregnancy considerably easier. The law was primarily means to address the issue of unwanted pregnancies, as a part of comprehensive family-planning strategy (Amold et al, 2002). There were two vital factors, pre-natal sex determination and liberal law on abortion has been responsible to develop cultural prejudices against the girl child. The ratio favourable to boys and adverse to girls coincides with the introduction of modern pre-natal sex determination methods (Bhat, 2002). The gender biasness resulting into low status of women and neglect of girl child are leading to higher risk of mortality (Arnold et al, 1998, Sen, 1992). The cultural preference for the son, sex sequence and number of sons (Das gupta, 2005 and George \& Dahia, 1998), societal changes rendering less space to daughters (Larson \& Hatti, 2008), abuse of sex determination technique (Garg \& Nath, 2008) and small-family culture has created an in balance in the sex combination.

Historically, the practices of female infanticide in India were limited among the upper caste group. It was due to custom of hyper gamy. And now it is being practiced by the people belong the middle and lowmiddle income groups of the society.

According to census of India which indicates a considerable increase in the literacy rate, reduction in overall growth rate, reduction and improvement in the sex ratio. The most distinguish features in the contradictory trends in the sex ratio of the general population and among the children under the age of six (EPW 2011). According to census 2011, the child sex ratio in India which was 927 in India, fell down to 914 in 2011, the conventionally sex ratio, experienced the highest increase (48 point) in the child sex ratio in the country during the same period (2001-2011) and the child sex ratio. Ashish Bose (2011) a well known demographer has also committed that his field work does not conform to the census findings so the evaluation of census data is required to find out the truth. More ever Punjab and Haryana are almost at the bottom of the list of states on child sex ratio, recorded no case of conviction under Pre-Conception and Pre-natal Diagnostic Technique (PC \& PNDT) Act in 2011 (The Tribune, 2012). This shows the 'pit falls' in the preventive measures, taken by the States of Punjab and Haryana.

Hence, it is obvious that the problem of female foeticide is being aggravated in both the states. The magnitude of the problem, requires an extensive awareness programme for the people, belong to different strata of society. Keeping in view the gravity of the problem, it becomes imperative to take some of preventive and curative methods, so that the combative measures may be executed in accordance with the prevailing conditions.

\section{Objectives Of The Study}

The main objectives of the study are:-

1. To study the sex ratio of the children of sampled couple from the rural and urban areas of each district; of Punjab and Haryana;

2. To study the role of age, religion, caste structure, family structure, education, occupation and income as determinates of female foeticides;

3. To find out the magnitude of female foeticide problem in Punjab and Haryana state;

4. To test the Hypothesis urban-rural disparity of female foeticide through t-test in Punjab and Haryana.

\section{Methodology}

The study is based on a sample of 100 respondents from Punjab and 100 respondents from Haryana. There are 200 samples of respondents have been studied from both the states. Amongst these respondents exactly half of samples, of male and female, have been taken from the rural areas of each district, belonged to Punjab and Haryana. All these urban and rural areas of Punjab and Haryana, indicates the average child sex ratio (0-6yrs) for different successive years (2001-2011) and collected from different towns and villages, taken for the study.

The survey was conducted in 2011-12. As a case of census, the number of female per thousand males has been taken as a sex-ratio. Data has been tabulated by applying simple statistical technique of percentages to interpret the results. In order to testify the trends of female foeticides between urban and rural areas, for the states Punjab and Haryana,

A 't-test' has been applied to get the desired results.

Testing of Hypothesis: In order to testing the hypothesis a 't-test' technique has been employed for drawing the desired inferences.

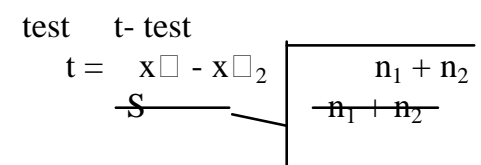


Here, 't- test' is based on ( $\mathrm{n}-2)$ degree of freedom. If the calculated value of $t$ ' exceed 0.05 for d.f. we say that the value ' $r$ ' is significant at 5 per cent levels.

On the basis of observed data, the 'Mean' and 'Standard Deviation' has been worked out for the respondents belonged to 'Urban' and 'Rural' areas. And subsequently, a 'calculated value' as well as 'tabulated value' have been worked out in accordance with the desired results.

\section{Results \& Discussion}

Punjab and Haryana are one of the most prosperous states of India which has been famous for its growth and development, but it is notorious for its imbalanced sex ratio. The general sex ratio of Punjab and Haryana have been improved from 876 in 2001 to 893 to 2011 in corresponding figures of sex ratio of India i.e. from 933 (2001) to 940 (2011). The increase in general sex ratio of shows that female mortality has increased because of improvement in pre-natal and post-natal medical facilities provided by the states derived National Rural Health Mission launched on April-1, 2005 in both the states. Although, female mortality has substantially declined, yet it is counter balanced by another type of pre-natal mortality that is sex specific and against a female foetus. As a result, in the case of sex ratio of India, the figures came down from 927 in 2001 to 914 in 2011. The latest child survival data collected by UNICEF also state that in India under 5 female mortality rates has been found to be higher (64), as compare to male, which are 58 .

On the basis of empirical study, carried out in both the states, indicate a considerable variability on the attitude from the households, belong to rural and urban areas. According to census 2011, all the districts of Punjab have recorded more than 800 child sex-ratio and it ranges 819 in Taran Taran district and 879 in S.B.S Nagar district. The highest improvement has been experienced as 87 points in child sex ratio is recorded in Kapurthala district while the lowest recorded in Muktsar district. The prejudicious tendency has been justified from the respondents by the 14.65 per cent of male and 18.93 per cent of female respondents, who have justified with various arguments.

Keeping in view the statistical figures of Haryana, which is comprised of the districts such as Sonepat, Rohtak and Jhajjar, just coincides with the Tarantaran district of Punjab. The trend of districts of Haryana also indicate more or less same situation. It has been observed that the sex-ratio (0-6 yrs), shows below services, available within this regions and the mind-set of the people, belonged to these areas. All these factors have given rise to female foeticide incidents within these prosperous regions of Haryana. In case of southern part, which includes the Rewari and Mahandergarh districts of Haryana, generally indicate prejudicous attitude against girl child. It has been observed that the overall situation of Rohtak Sonepat and Jhajjar districts of Haryana indicate that 14.09 per cent of the male and 16.13 per cent of the female respondents. On the other hand there were the areas in southern region of Haryana which indicate their less than 800 female (0-6yrs) per 1000 male sex ratio. It has also been observed that the mind-set of the respondents belong to rural and the urban areas indicate their views more or less same within these districts.

Keeping in view the district-wise of the respondents on various attitudes taken from Punjab and Haryana and the statistical figures of 2011 census indicate more or less same trends of sex-ratio of general population and 0-6 age groups, which indicate a considerable variability between general sex ratio and the child sex-ratio (0-6 yrs age-group) in both of states. It has been observed that there have been most of common reasons such as agrarian social structure, preference to the male child, general mind-set of the people which shows the prejudices against the girl child, growing economy of the rural areas and some of other social flaws like dowry system which have given rise to increasing the 'female foeticide' in urban \& rural areas of Punjab and Haryana states.

Punjab and Haryana Region: Sex Ratio General and 0-6 Age Group-2011

\begin{tabular}{|c|c|c|c|c|c|c|}
\hline $\begin{array}{c}\text { Sr } \\
\text { No. }\end{array}$ & State/ District & $\begin{array}{c}\text { Sex Ratio } \\
\text { General }\end{array}$ & $\begin{array}{c}\text { Sex Ratio (0-6 } \\
\text { age group) }\end{array}$ & State / District & $\begin{array}{l}\text { Sex Ratio } \\
\text { (General) }\end{array}$ & $\begin{array}{c}\text { Sex Ratio } \\
\text { (0-6 age group) }\end{array}$ \\
\hline 1. & Gurdaspur & 895 & 824 & Panchkula & 870 & 850 \\
\hline 3. & Jalendhar & 913 & 874 & Yamuna Nagar & 877 & 825 \\
\hline 4. & Hoshiarpur & 962 & 859 & Kurukshetra & 889 & 817 \\
\hline 5. & SBS Nagar & 954 & 879 & Kaithal & 880 & 821 \\
\hline 7. & Ludhiana & 869 & 865 & Panipat & 861 & 833 \\
\hline 8. & Moga & 893 & 865 & Sonipat & 853 & 790 \\
\hline 9. & Firojpur & 893 & 846 & Jind & 870 & 835 \\
\hline 10. & Mukatsar & 895 & 830 & Fatehabad & 903 & 845 \\
\hline 11. & Faridkot & 889 & 851 & Sirsa & 896 & 852 \\
\hline 12. & Bhatinda & 865 & 854 & Hissar & 871 & 849 \\
\hline
\end{tabular}




\begin{tabular}{|l|c|c|c|c|c|c|}
\hline 15 & Amritsar & 884 & 824 & Jahjjar & 861 & 774 \\
\hline 16 & Taran Taran & 898 & 819 & Mehander Garh & 894 & 898 \\
\hline 17 & Rup Nagar & 913 & 866 & Rewari & 784 \\
\hline 18 & SAS Nagar & 878 & 842 & Gurgaon & 853 & 826 \\
\hline 19 & Sangrur & 883 & 835 & Mewat & 906 & 871 \\
\hline 20 & Barnala & 876 & 847 & Faridabad & 843 \\
\hline 21 & - & - & - & Palwal & 879 & 862 \\
\hline
\end{tabular}

Source: - Census of India (Haryana \& Punjab-2011)

In order to know the trends of practices of female foeticides in urban and rural areas, there were 9 districts, as sample districts have been chosen for the study. Further, all these nine districts of both states have two towns having urban child sex ratio and two sample villages which show rural child-sex ratio (0-6 year's age-group). In order to know difference of the practices of 'female foeticides' in difference in urban and rural areas, two towns and two villages have been taken for the study. In order to know the factual picture of 'female -foeticide' a Hypothesis has been developed-Hypothetically It has been assumed that there is considerable difference between child sex-ratio (0-6 years) in urban and rural areas which indicate that there is considerable difference of 'female-foeticide' between urban and rural areas of Punjab and Haryana.

In order to know the 'factual picture' of female foeticide, there were nine sample districts have been chosen for the study. Further, all these nine districts were having two towns and two villages for each districts have been selected as sample town and sample village respectively. For all these urban and rural areas, the data on child sex ratio have been collected from the Municipal corporation/ Municipal committee / Gram Panchayat from different districts, taken for the study.

In order to know the trends of practices of female foeticides in urban and rural areas, there were 9 districts, as sample districts have been chosen for the study. Further, all these nine districts of both states have two towns having urban child sex ratio and two sample villages which show rural child-sex ratio (0-6 year's age-group). In order to know difference of the practices of 'female foeticides' in difference in urban and rural areas, two towns and two villages have been taken for the study.

TABLE: 2

\section{DISTRIBUTION OF SAMPLE DISTRICTS OF CHILD SEX RATIO (0-6Yrs) OF PUNJAB \& HARYANA}

HARYANA

PUNJAB

\begin{tabular}{|c|c|c|c|c|c|c|}
\hline Sr.No & DISTRICT & Urban sex- ratio & $\begin{array}{l}\text { Rural sex- } \\
\text { Ratio }\end{array}$ & DISTRICT & Urban sex-ratio & Rural sex-ratio \\
\hline 1 & Gurdaspur & $\begin{array}{c}\text { Gurdaspur } 820 \\
\text { Pathankot } \\
888\end{array}$ & $\begin{array}{c}\text { Jawahar } \\
896 \\
\text { Jakodi } \\
882\end{array}$ & Ambala & $\begin{array}{c}\text { Ambala } \\
882 \\
\text { Dhulkot } \\
881\end{array}$ & $\begin{array}{c}\text { Kesri } \\
880 \\
\text { Shahbad } \\
\text { Markanda } \\
882\end{array}$ \\
\hline 2 & Jalandhar & $\begin{array}{c}\text { Jalandhar } \\
871 \\
\text { Phagwara } \\
869\end{array}$ & $\begin{array}{c}\text { Surnasi } \\
870 \\
\text { Suchi Pind } \\
860\end{array}$ & Karnal & $\begin{array}{c}\text { Karnal } \\
889 \\
\text { Neelokheri } \\
886\end{array}$ & $\begin{array}{c}\text { Uchani } \\
881 \\
\text { Aungad } \\
880\end{array}$ \\
\hline 3 & Patiala & $\begin{array}{c}\text { Patiala } \\
830 \\
\text { Zirakpur } \\
829\end{array}$ & $\begin{array}{c}\text { Lalru } \\
813 \\
\text { Dokola } \\
825 \\
\end{array}$ & Rohtak & $\begin{array}{c}\text { Rohtak } \\
890 \\
\text { Meham } \\
866 \\
\end{array}$ & $\begin{array}{c}\text { Makrauli } \\
879 \\
\text { Bahu Akbarpur } \\
880\end{array}$ \\
\hline 4 & Faridkot & $\begin{array}{c}\text { Faridkot } \\
872 \\
\text { Kotkapura } \\
890\end{array}$ & $\begin{array}{c}\text { Moranwali } \\
876 \\
\text { Banawali } \\
896\end{array}$ & Sirsa & $\begin{array}{c}\text { Sirsa } \\
889 \\
\text { Dabawali } \\
896\end{array}$ & $\begin{array}{c}\text { Ratta Khera } \\
888 \\
\text { Rupam Khurd } \\
882\end{array}$ \\
\hline s5 & Tarantaran & $\begin{array}{c}\text { Tarantaran } \\
820 \\
\text { Patti } \\
869\end{array}$ & $\begin{array}{c}\text { Jandoke } \\
816 \\
\text { Dukhara } \\
860\end{array}$ & Bhiwani & $\begin{array}{c}\text { Bhiwani } \\
889 \\
\text { Charkhi Dadri } \\
881\end{array}$ & $\begin{array}{c}\text { Bamla } \\
880 \\
\text { Bound } \\
878\end{array}$ \\
\hline 6 & Bhatinda & $\begin{array}{c}\text { Bhatinda } \\
870 \\
\text { Malaut } \\
860\end{array}$ & $\begin{array}{c}\text { Rampurphul } \\
865 \\
\text { Ballona } \\
855\end{array}$ & Mahendergarh & $\begin{array}{c}\text { Mahendergarh } \\
899 \\
\text { Narnaul } \\
890\end{array}$ & $\begin{array}{c}\text { Garhi Bolni } \\
891 \\
\text { Dharsu } \\
879\end{array}$ \\
\hline 7 & Sangrur & $\begin{array}{c}\text { Sangrur } \\
880 \\
\text { Malerkotla } \\
867\end{array}$ & $\begin{array}{c}\text { Bhurur } \\
872 \\
\text { Bhatiadul } \\
860\end{array}$ & Gurgaon & $\begin{array}{c}\text { Gurgaon } \\
888 \\
\text { Pataudi } \\
890\end{array}$ & $\begin{array}{c}\text { Pachgaon } \\
878 \\
\text { Bohra kalan } \\
892\end{array}$ \\
\hline 8 & Firozpur & $\begin{array}{c}\text { Firozpur } \\
890 \\
\text { AboharMandi } \\
893\end{array}$ & $\begin{array}{c}\text { Hussainiwala } \\
890 \\
\text { Kasubanga } \\
885\end{array}$ & Mewat & $\begin{array}{c}\text { Nuh } \\
906 \\
\text { Firozpur Jhirka } \\
904\end{array}$ & $\begin{array}{c}\text { Ghasera } \\
999 \\
\text { Mandikhera } \\
969\end{array}$ \\
\hline
\end{tabular}


Evaluating The Magnitude Of Female Foeticide Problem Of Punjab And Haryana

\begin{tabular}{|c|c|c|c|c|c|c|}
\hline 9 & Ropar & $\begin{array}{c}\text { Ropar } \\
867 \\
\text { Morinda } \\
860\end{array}$ & $\begin{array}{c}\text { Kurali } \\
886 \\
\text { Dhankoli } \\
872\end{array}$ & Palwal & $\begin{array}{c}\text { Palwal } \\
890 \\
\text { Hodals } \\
879\end{array}$ & $\begin{array}{c}\text { Fatehpur Baloch } \\
861 \\
\text { Shahelka } \\
864\end{array}$ \\
\hline
\end{tabular}

Source: Field study

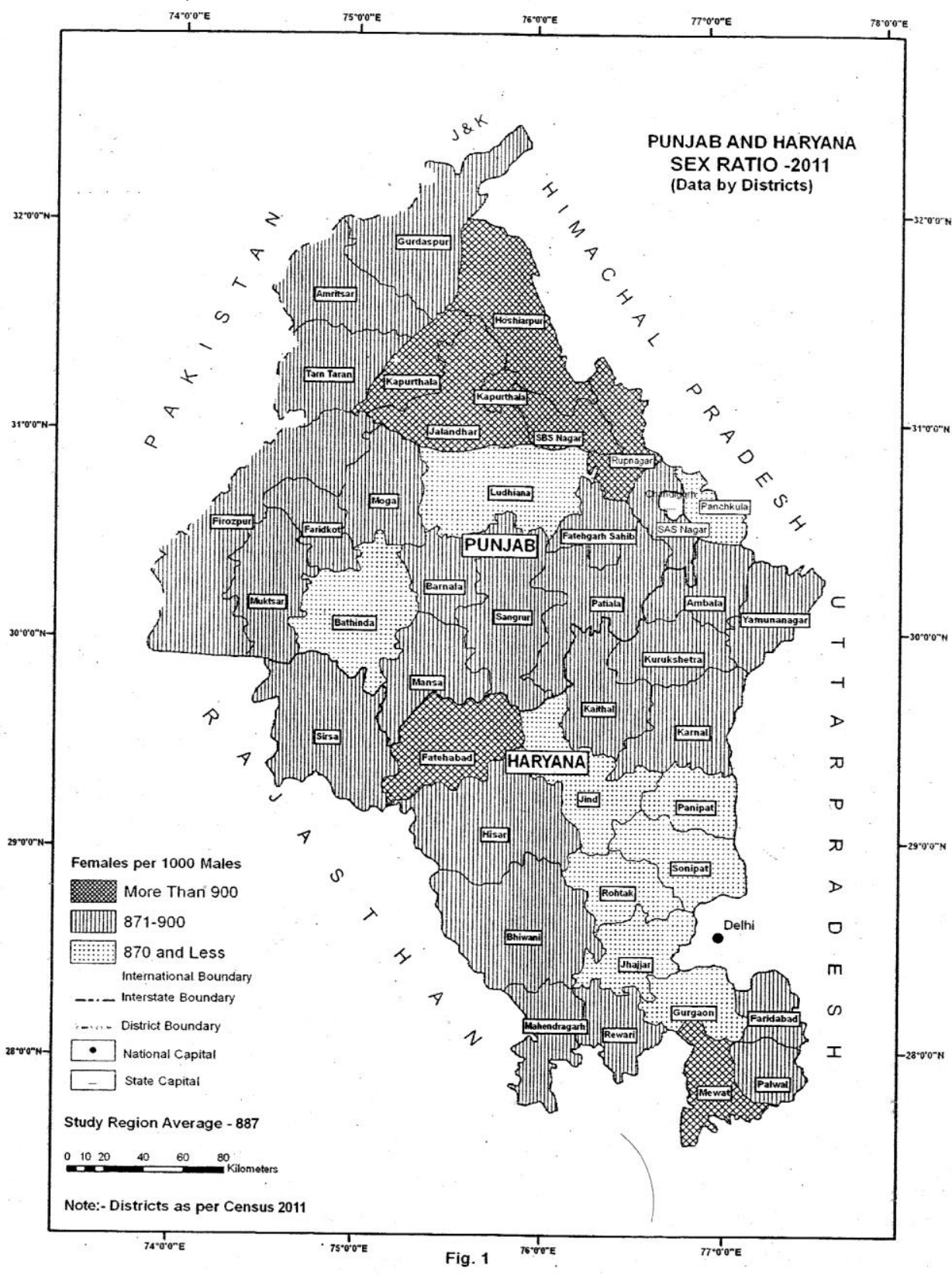




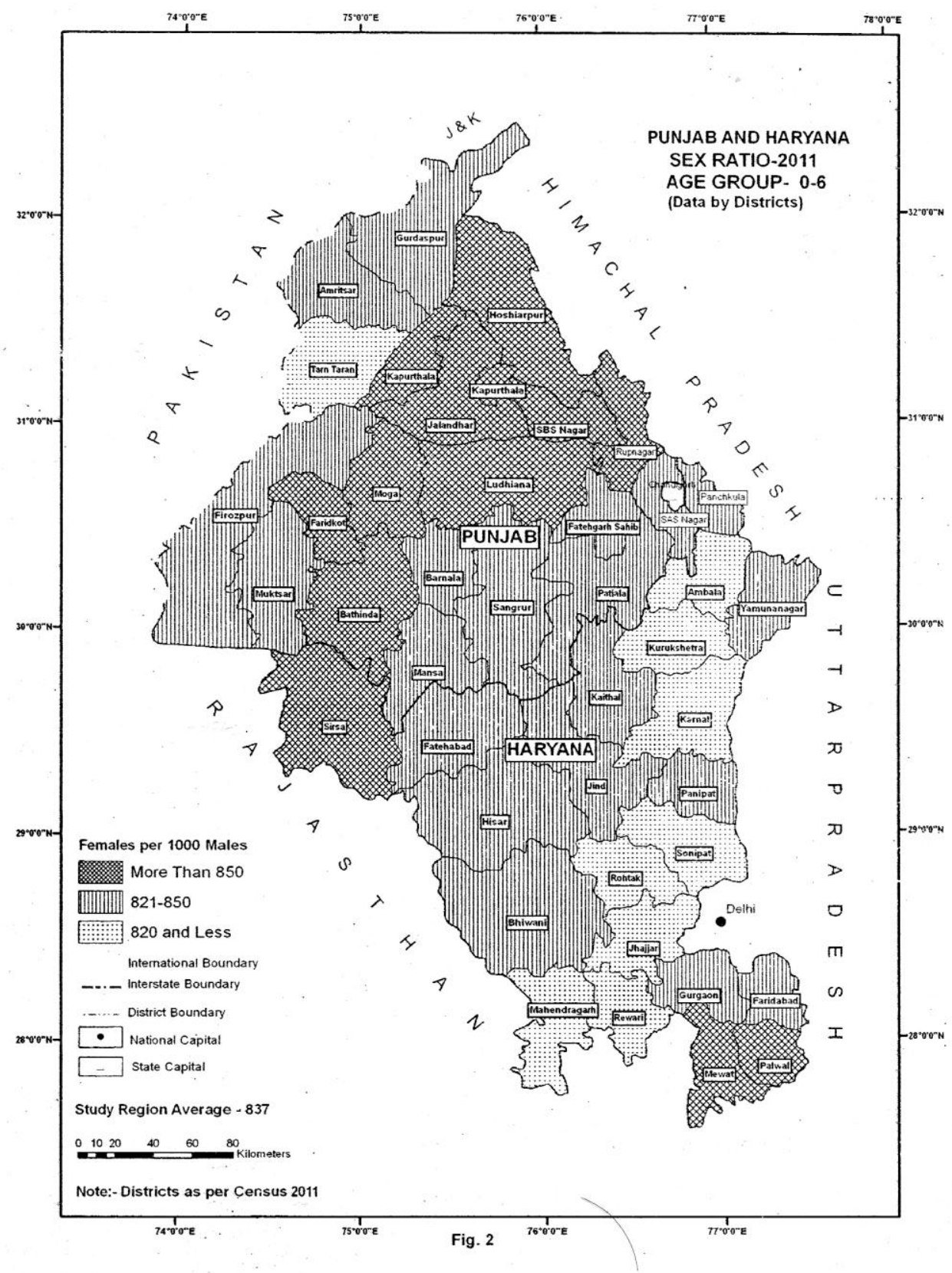

Keeping in view the tabulated figures of child sex-ratio (0-6 yrs) of urban and rural areas of Punjab \& Haryana, we may analysis the 'female foetiside' problem in accordance with 'Regional Perspective'. In case of Punjab, it has been observed that the district Jalandhar, (Doaba region) indicate relatively low Figure of child sex-ratio ( $0-6$ yrs) and the situation of rural areas were more or less same, as indicated by the tabulated data of sample villages like Jawahar, Jakoldi and Surnasi, show their child sex-ratio (0-6 yrs). In this region, it has also been observed that the urban child sex-ratio of Phagwara district was 869 female per female. The corresponding figures of child sex-ratio in rural areas such as Suchipind indicate its figure as relatively lower sex-ratio figure (860). In case of Patiala district, the child sex-ratio figure in urban areas was, such as Patiala (830) and Zirakpur (829). In case of rural areas, the position of child-sex ratio has been relatively lower, as it was clear from the sample villages such as Lalru (813) and Dokola (825). In case of Faridkot district which shows the urban child sex-ratio indicate as 872 for Faridkot and 890 per thousand male for Kotkapura. On the other hand, the situation of rural areas is slightly better, as indicated by the sample villages, like Moranwali (876) and Bananwali (896).

In case of Tarantaran district, there is considerable regional disparity within the district even. It is obvious from the tabulated figures of the district which indicate that the child sex ratio of Tarantaran and Patti 
towns have been 890 and 869 respectively. On the other hand, it has been observed that there has been considerable variability within the rural area of the district too. However, the child sex ratios of Jandoke and Dukhara have 816 and 860 respectively. In case of Bhatinda district, the urban-rural regional disparity has been denoted by the minor difference of child sex-ratio. It has been noticed that the child sex-ratio (0-6 yrs) of Bhatinda and Malaut town have been 870 and 860 per thousand male respectively. On the other hand, the child-sex ratio of the sample villages like Rampur phul and Ballona indicate their child sex-ratio 865 and 855 female per thousand male respectively.

In case of Sangrur district, it has been observed that there is considerable regional disparity between the two sample towns even. In Sangrur district, as we observe from the tabulated figures which indicates that the child sex-ratio (0-6 yrs) of Sangrur and Malerkotla towns have been $880 \& 867$ female per thousand male respectively. Same trend has been noticed in rural child sex ratio of the sample villages like Bhurur (872) and Batiadur (860).

In case of Firozpur district, it has been found that there was minor difference in child sex ratio (0-6 yrs) within the two towns, selected for the study. However, the child sex-ratio between Firozpur city and Abohar Mandi has been 890 and 893 female per thousand male respectively. Same trend has been noticed for the child sex-ratio in rural areas of Firozpur district. There was minor difference between Hussainiwala (890) and Kasubanga (885). Lastly, the district Ropar, indicate the trends of urban-rural regional disparity with slightly different ways. The child sex ratio of urban and rural areas were 867 and 860 for Ropar and Morinda towns, whereas the child sex-ratio of the rural areas have been 872 and 860 female per thousand male respectively in Kurali and Dhankoli villages.

Keeping view the tabulated figures of child birth rates, within the age group of 0-6 years, of Haryana which indicates fluctuating figures for urban and rural areas, as shown in the table 2. In case of Ambala district, the child sex-ratio of urban and rural areas, were 882 and 881 female per thousand male for Ambala and Dhulkot towns respectively. On the other hand, the child sex ratio of rural areas which includes the villages Kesari and Shahbad Markanda were 880 and 882 female per thousand male respectively. In case of Karnal district, same trend has been observed for Karnal and Nilokheri Towns, as indicate their child sex-ratio as 889 and 886 female per thousand male respectively. For rural areas, a minor difference has been noticed in the sample villages' i.e. Uchani and Aungad, as indicate their child sex-ratio as 881 and 888 female per thousands male respectively. In case of Rohtak district, it has been observed that there is considerable 'Regional Disparity' noticed in child's birth rates (0-6 yrs) at Rohtak and Meham towns, which were 890 and 866 female per thousand male respectively. In case of rural areas of Rohtak district, the sample villages Makrauli and Bahu Akbarpur indicates their child sex ratio (0-6 yrs) as 879 and 886 female per thousand male respectively.

In case of Sirsa district, the child sex-ratio (0-6 yrs) of urban areas was 899 and 866 female per thousand male for Sirsa and Dabawali towns respectively. On the other hand, in rural areas the corresponding figures of child sex-ratio (0-6 yrs) were 888 for Ratta Khera and 888 for Rupam Khure. It means, the figures of child ratio were relatively lower in rural areas. In case of Bhiwani district, the tabulated figures show that the child sex ratio of urban areas which includes Bhiwani (889) and Charkhi Dadri (881). The corresponding figures of rural areas were 882 and 880 for the sample villages like Bamla and Bound respectively. In case of Mahendergarh district, the child sex-ratio was 899 and 890 female per thousand male of Mahendergarh and Narnaul towns. On the other hand, the sample villages like Nangal chaudhry and Dharsu were having their child sex-ratio 878 and 891 female per thousand male respectively. Meaning thereby, there is considerable difference in child sex ratio within the rural areas even.

In case of Gurgaon district, the child sex ratio (0-6 yrs) was 888 and 890 female for Gurgaon and Pataudi towns respectively. On the other hand, the child sex -ratio in rural areas, were 878 and 892 for Pachgaon and Bohra Kalan respectively. In case of Mewat district, the child sex ratio (0-6 yrs) was 906 and 904 female per thousand male for the urban areas like Nuh and Firozpur Jhirka respectively. On the other hand, the child sex-ratio for rural areas of Mewat district, indicate as 999 and 904 female per thousand male in Ghasera and Mandikhera villages respectively.

Lastly, the Palwal district shows more or less same figures of child sex-ratio, as we observe 880 and 879 female per thousand male for Palwal and Hodel towns respectively. On the other hand the corresponding figures for rural areas also indicate more or less same trend, i.e. 861 and 864 female per thousand male for the villages Fatehpur Bloch and Shaolka respectively.

Keeping in view the tabulated figures of child sex-ratio (0-6 yrs) of Punjab and Haryana, which indicate that the Doaba region of Punjab and Palwal district of Haryana, indicate a relatively lower figures. The trends of urban and rural child sex-ratio do not indicate any considerable difference too. It is obvious that almost every district of Punjab and Haryana is having below average child sex ratio, except Mewat region, where the highest child sex ratio (0-6 yrs) has been registered. It is because of strong prejudices against deliberate check on child birth and due to religious taboo, child birth rate always been high for decades. 
Hence, it is obvious from the various tabulated figures which show a regional disparity in 'general sex ratio' and the child sex-ratio (0-6 years) of different districts of Punjab and Haryana. The difference between the 'general' and child sex-ratio (0-6 yrs) indicate a clear cut regional disparity of practices of 'female-foeticide' intensity in different districts of Punjab and Haryana states. It is one of most affected parts of north-western India which has been suffering for the decades even.

Keeping in view the tabulated data of child sex-ratio, between the age-group of 0-6 years, indicate the probability of female-foeticide of Punjab and Haryana, have been testified by t-test, which have drawn the inferences as follows:

\section{PUNJAB}

$$
\text { Suppose Null Hypothesis } H_{0}: \mu=\mu_{0}
$$
SAMPLE
URBAN
RURAL
Calculated value
Tabulated

value

\begin{tabular}{|c|c|c|c|c|}
\hline MEAN & 863.6 & 864 & & \\
\hline & & & -0.025 & 1.734 \\
\hline S.D & 21.54 & 26.05 & & \\
\hline
\end{tabular}

Hence, it is obvious that the calculated value of Punjab is less than the tabulated value, which is not significant (At $5 \%$ sample taken for the study). Meaning thereby, the sex-ratio of child of age-group (0 -6) is more or less same in the urban and rural areas of Punjab. In other words, the probability of female foeticide is more or less same in the urban as well as rural areas of Punjab.

\section{HARYANA}

Suppose Null Hypothesis $H_{0}: \mu=\mu_{0}$

SAMPLE

URBAN

RURAL

Calculated value

Tabulated

value

\begin{tabular}{|c|c|c|c|c|}
\hline MEAN & 936.72 & 891.33 & & \\
\hline & & & -0.035 & 1.371 \\
\hline S.D. & 9.52 & 15.03 & & \\
\hline
\end{tabular}

Hence, it is obvious that the calculated value of Haryana is also not significant (At $5 \%$ sample taken for the study). Meaning thereby, the child sex ratio of age-group (0-6) is more or less same in the urban and as well as rural areas of Haryana. In other words, the probability of female foeticide is more or less same in the urban as well as rural areas of Haryana.

Keeping in view of the census -2011, based statistical figures of Punjab and Haryana which indicate that Punjab sub-region has relatively higher sex-ratio (both general and child) than Haryana sub-regions, which have demarcated as zones. (II) Bist-Doab belt along with Rup Nagar and SBS Nagar in Punjab and Mewat and Fatehabad districts in Haryana reveal a figure of higher sex-ratio of over 900 (iii) the industrial belt, along with G.T. Road in Haryana and Punjab and emerging industrial district of Bathinda reveal a relatively lower figure of sex-ratio i.e. 870; (iv) rest of the region had a sex ratio nearer to the regional average. (v) The pattern of child sex ratio (0-6 yrs) is more or less same with the general sex-ratio. (vi) Child sex ratio in Haryana sub-regions (zones) was relatively lower than that in Punjab sub-region.

The low sex-ratio pattern is closely associated with the relatively small holdings and the out-migration, where the remittances sent by such emigrants provide positive feedback to stimulate further migration especially of males in search of better occupation (ii) the Mewat region which is characterized with low literacy rate, general backwardness and religions prejudices against female-foeticide, have cumulatively been given rise to higher sex ratio of the children (0-6 yrs) age group. It has been justified by the respondents of the villages of 'Mandhi khera' too. The Mewat area of higher sex-ratio coincides with the Sirsa district too. However, the study on the respondents of the villages Sanjarwas and Pirthalal(Fatehabad) have also indicated higher level of awareness on this issue. Overall the situation of Hisar, Bhiwani, Fatahabad and Sirsa indicate a higher to moderate child sex-ratio. The moderate child-ratio of other districts of Punjab such as Mansa, Sangrur and Barnala. The range of child-ratio is from 821 to 850 female per 1000 males, has also found in the rural areas such as Kokli Kala and Bhamur, belonged to Mansa and Sangrur districts, indicates higher level of awareness on the 'female foeticide issue'. In this context, that the districts belong to western Punjab, which includes Amritsar and Gurdaspur indicate more or less same trend of female foeticide problem. In the rural areas, where a considerable number of households of the villages Jandiala and Surnasi of Amritser and Jalandhr districts indicate their liberal views on the female foeticide issues. In Haryana, some tendency has been observed by the overall response of the districts Panipat and Yamuna Nagar, where the range of child sex ratio is from 821 to 
850 female per 1000 males. Though both districts, belonged to prosperous region, but there are the households, belonged to Bapoli village (Panipat), who have highlighted the preference of male child. In Yamuna Nagar district, 12.33 percent of the male and 18.32 per cent of the female, respondents have revealed their attitudes towards 'male child preference'. In this context, the respondents, belongs to Gurgaon and Faridabad also found to tend towards the same-tendency, towards male-child preference. Despite higher level of urbanism within both of these cities, the respondents belong to rural areas such as Panchgon and Mandavali village have indicated more or less same views on this problematic areas.

Cause-effect relationship of the problem of female foeticide: In order to establish the 'cause-effect' relationship of level of incidence of 'female-foeticide' and the factors affecting the problem of female-foeticide in an area. In the context, the regional disparity has been determined by the some of socio-economic and institutional factors which have affecting the 'Magnitude of female foeticide problem in this north-western region of India.

In this context, the religion ranks first, where the Sikhs and the Hindus are predominant in Punjab. In Haryana, Hindu is a dominant region, followed by Sikhs in Karnal, Kurukshetra and Sirsa districts. The sexratio of the Children is lowest in the Sikhs. Their love for the agricultural land which further require male for inheriting and cultivating. It was observed in some of the respondents, belonged to Dhandhari Kala (Ludhiana) and Surnasi (Jalandhar). In this context, similar situation has been found in Dheerpur (Kurukshetra) and Uchani (Karnal) villages of Haryana. All these areas indicate less than low child ratio (less than 820 female per 1000 female). On the contrary, the Mewat region of Haryana where the Islam is practiced by 85 per cent of the 'Meos' in whole district of Mewat and Hathin Tehsil of Palwal district. It has been observed that the 'Meos' are having a strong prejudices against the family planning and the female foeticide practices. As a result, indicate highest child sex-ratio (906) in whole North-western region of India (census, Haryana 2011).

Secondly, the cast structure plays an important role for dividing the settlement units of rural and old urban settlement. The general caste recorded lower sex-ratio than the scheduled castes and other backward classes. This trend has been observed by the respondents, belonged to Kokli Kali village of Mansa district of Punjab. In case of Haryana, the respondents of Makrauli village of Rohtak indicate more or less same trend.

Thirdly, the family structure plays a vital role for son preference which is found in the couples of joint families. It has been observed that the intense family pressure of must having a son especially in the joint families in affecting the sex-ratio, especially in the rural areas. This tendency has been observed in both the states. The Bassi Pathana village of Fatehgarh Sahib and Kitabpur village of Kaithal district of Haryana, indicate more or less same mind-set of the people for preferring the male child for their families.

Fourthly, the education plays a significant role for acquiring the knowledge \& awareness. In this study declining son preference has found among the couples, mostly well educated, belong to urban areas. In the context, low sex ratio among the (0-6 yrs) age group of the children in Rohtak, Jhajjar, Sonipat, Faridabad district indicate relatively lower sex ratio. It is because of higher level of literacy within these districts. The highly educated group has more exposure and knowledge of sex determining technique etc.

Fifthly, the occupation also plays a significant role for determining the sex-ratio. In this study, it has observed that the children belonged to agricultural class have the lowest sex-ratio. Agricultural land is considered to be family asset and sons are prepared more than daughters in order to retain the land in the families land. On the other hand, the service and the business class are having a better sex ratio. The educational level, as a deciding factor has been elaborated with the various respondents, belonged to rural and urban areas of Punjab and Haryana.

Lastly, the income determines the preference for son. It has been observed that the higher income groups, are having no preference of boys or girl. On the other hand, the respondents, belonged to lower income groups have relatively preferred the son. This trend has been observed in almost all the districts of Punjab and Haryana.

\section{Conclusion}

The present study concluded that the sex-ratio of both the states have been determined by the socioeconomic and institutional factors. It cannot be denied that the psyche of the people that propagates and ideas of son preference is still deep rooted in our society. The Majority of the urban and rural population wants to have only one or two children. The policy of the family planning implemented by the Government has further aggravated the problem as people started limiting their family but in the favour of son. This tendency has given rise to occurring the incidents of female foeticide in rural and urban areas of Punjab and Haryana. In both the states, the Mewat area of Haryana is only area which does not indicate the incident of 'female foeticide'. It has because of strong religious prejudices against deliberate check on birth. They consider it as sin. The advent of new technology and its vast exposure has made it easier for the couples to know the sex of the child before birth. Although the use of such technologies to determine the sex of the unborn child is banned yet sex determination and abortion of female foeticide are still going on in almost all the areas of Punjab and Haryana. If this 
phenomenon continues for some more years along with the attitude of son preference among the people, it will surely raise most threatening demographic crises in both the states. On the bases of study carried out on some of urban and rural areas of Punjab and Haryana do not indicate much difference in female foeticide, as indicated by t-test for same towns and villages, selected for the study. Lastly, there were some of suggestions which are very essential to ameliorate the present situation of 'female foeticides' for both the states, only then it will be justice for declining Girl child sex-ratio in whole north-western part of India.

\section{SUGGESTIONS}

- The religious leader should make their followers aware of the adverse effects of declining sex ratio.

- The media can play a vital role for creating awareness on this sensitive issue.

- There should be strictly follow the PNDP Act. The culprit should be punished accordingly.

- The most important way to change the mind-set of the people, belong to different strata of society in rural and urban areas.

- The labour class and the people, belong to BPL (below poverty line) should also be provided with some social security measures which may incline them in favour of girl child. The govt. programme like 'Laadli' should be promoted in all the low sex-ratio affected states.

\section{References:-}

[1]. Armold, F. Choe, M.K. Roy, T.K. (1988): Son Preference, the Family Building Process and Child Mortality in India, Population Studies 52(3), p. 302.

[2]. Armold, F. Choe, M.K. Roy, T.K. (2002): "Sex Selective Abortions in India", Population and Development Review, (4) p.28.

[3]. Bhat, P.N. M. (2002) ' On the trail of "Missing Indian Females Illusion and Reality" Economic and Political Weekly, 37 (52), p. 5105

[4]. Bhat, P.N. M. and Zavier, A.J.F. (2003), 'Fertility Decline and Gender Bias in Northern India,' Demography, 40 (4), p. 637

[5]. Bora (2007)' Imbalance in Child sex Ratio: Trends Causes and Emerging issue" accessed from www.ieindia.org/work/pop/wp280.pdf.p1.

[6]. Clark, S.(2002): 'Son preference and and Sex Composition of Children : Evidence from India', Demography, 37 (i) p. 85.

[7]. Garg, S and Nath, A (2008): "Female Foeticide in India: Issues and concerns, 'Journal of Post Graduate Mediciens, 54 (4), p.276.

[8]. George, S.M. and Dahiya, R.S. (1998): 'Female Foeticide in Rural Haryana Economic and Political weekly, 33 (32), p, 2191.

[9]. Kaur, M. (2003), 'Socio-cultural correlates of Low Sex-ratio in Punjab in Gill M.S. (ed). Punjab Society; Perspective and Challenges, Concept publishing company, New Delhi, p.44.

[10]. Kumari, R (2006), 'Female infanticide and Foeticide: The Declining Sex Ratio, 'A paper presented at National Conference on Violence against the Girl Child, Feb. 2006 at Jaipur p. 15.

[11]. Sen Amartiya (1992), Missing Women: Social inequality out weights Women's Survival Advantage in Asia and North Africa' British Medical Journal, 304 (6824) p. 587.

[12]. Singh, Joginder (2008) 'Demographical change in Mewat Region of Haryana: An unpublished PhD Dissertation, submitted in deptt. of Geography, Meerut, University, Meerut (U.P.)

[13]. Satyalpal (2009)' Execution of PNDT Act in Punjab and Haryana: An Analysis 'An Unpublished PhD Dissertation, submitted in Law Faculty, M.D. University, Rohtak. 